\title{
Korištenje društvenih mreža kod učenika osnovne škole The use of social networks among elementary school population
}

\author{
Ivana Kunić', Marina Vučković Matić2 , Joško Sindik \\ 'Stomatološka poliklinika „Raguž", Kneza Domagoja 5, 20000 Dubrovnik. \\ ${ }^{1}$ Stomatological Clinic „Raguž", Kneza Domagoja 5, 20000 Dubrovnik \\ 2 Osnovna škola Ivana Gundulića, Sustjepanska 4, 20000 Dubrovnik, Hrvatska. \\ 2Elementary School Ivana Gundulića, Sustjepanska 4, 20000 Dubrovnik, Croatia \\ ${ }^{3}$ Institut za antropologiju, Ljudevita Gaja 32, 10000 Zagreb, Hrvatska \\ 3Institute for Anthropological Research, Ljudevita Gaja 32, 10000 Zagreb, Croatia
}

\section{Sažetak}

Cilj: Društvene mreže, kao vrsta internetskog servisa i novi medij, koriste povezivanju i međusobnoj komunikaciji. S vremenom se pokazalo da osim pozitivnih učinaka, društvene mreže donose i niz po zdravlje negativnih učinaka. Glavni cilj istraživanja bio je utvrditi način korištenja „online" društvenih mreža kod učenika viših razreda osnovne škole te identificirati različita ponašanja učenika na „online" društvenim mrežama.

Metode: Ispitivanje je provedeno na namjerno odabranom uzorku od 225 učenika viših razreda (od 5.do 8. razreda) Osnovne škole "Lapad" u Dubrovniku. Rezultati su analizirani primjenom posebno sastavljenog anketnog upitnika, $s$ pitanjima razvrstanim u tematska područja istraživanja.

Rezultati: Pokazalo se da većina učenika uspješno koristi računalo i društvene mreže, najčešće svakodnevno, pristupajući internetu najčešće putem mobilnog telefona. Internet se najmanje koristi u obrazovne svrhe, a više u svrhu zabave. Oko 90\% ispitanih učenika ima svoj profil na nekoj društvenoj mreži. Glavni je razlog korištenja društvene mreže druženje s postojećim prijateljima, dok je rjeđi motiv upoznavanje novih ljudi. Roditelji ispitanika smatraju da njihova djeca provode previše vremena za računalom.

Rasprava i zaključci: društvene su mreže postale sastavni dio života osnovnoškolaca, i tek u manjoj mjeri mogu davati optimistična predviđanja o njihovim implikacijama na zdravlje djece, pa je preventivno djelovanje nužno.

Ključne riječi: medijski odgoj • ovisnost o internetu • preventiva • zdravlje

Kratki naslov: Društvene mreže i populacija učenika osnovne škole

\begin{abstract}
Objective: Social networks, as a type of Internet service and new media, are being used for linkage and mutual communication. Eventually, it turned out that, in addition to the positive effects of social networks, a range of health adverse effects could be expected also. The main objective of the study was to determine how the online social networking is used among students of higher grades of elementary school, by identifying different behaviors of the students on online social networks.
\end{abstract}

Methods: The research was conducted on purposely selected sample of 225 students in higher grades (from 5th to 8th grade) in the Elementary school "Lapad" in Dubrovnik. Results were analyzed using specially designed questionnaire, with the questions grouped into themed areas of research.

Results: It was shown that the majority of students successfully used computer and social networks, usually on a daily basis, accessing the Internet most often via smartphone. Internet is least used for educational purposes, but more for entertainment. About $90 \%$ of students have a profile on a social network. The main reason for the use of social networks is to socialize with existing friends, while less frequent motive is meeting new people. Parents of participants believe that their children spend too much time at the computer.

Discussion and Conclusions: Social networks have become an integral part of the lives of elementary school students, and only to a certain extent optimistic predictions about their implications for the children health could be presumed. Therefore, the preventive action is necessary.

Keywords: media education • internet addiction • prevention • health

Running head: Social networks and elementary school population

\section{Uvod/Introduction}

Masmediji i mediji su sredstva koje pružaju veliku dostupnost, raznovrsnost i brzinu informacija u suvremenom društvu [1]. Masmediji su primjerice novine, radio i televizija, dok su mediji npr. računalo, mobitel, elektronička pošta i telematičke mreže [1]. Funkcije medija su: informacijska (obavijesna), selekcijska, eksplikacijska, edukacijska, zabavna i estetska[1]. Mediji postaju glavni čimbenici socijalizacije, potiskujući školu i obitelj pa utječu na formiranje vrijednosti i stilova ponašanja mladih [2] te kreiranje slobodnoga vremena djece. Prekomjerno korištenje medija u slobodno 
vrijeme dovodi postupno do krize odgoja te inverzije vrednota, ali i do brojnih zdravstvenih problema poput ovisnosti[1]. Društveni mediji podržavaju ljudsku potrebu za društvenom interakcijom, olakšavajući dvosmjernu komunikaciju među ljudima, pružajući im mogućnost da dijele različite sadržaje (slike, tekstove, video i zvučne zapise) te da sami stvaraju medijske sadržaje [1].

\section{Komunikacije na društvenim mrežama}

Društvena mreža je posebna vrsta društvenih medija, tj. usluga temeljena na world-wide-web-u koja omogućuje pojedincima da izgrade javni ili polu-javni profil unutar omeđenog sustava, artikuliraju listu drugih korisnika s kojima dijele vezu, koristeći vlastiti popis veza i popise veza drugih unutar sustava[1]. Društvene mreže predstavljaju opći komunikacijski fenomen, možda stoga što je čovjek po prirodi društveno biće i komunikacija ga kao takva privlači [3]. Socijalna uloga društvenih mreža povezana je ponajprije $s$ jednostavnim postupkom održavanja postojećih poznanika i prijatelja, otvarajući ujedno mogućnost sklapanja novih poznanstava [4]. Većina ljudi koristi današnja tehnološka dostignuća zbog paralelnog obavljanja više aktivnosti (npr. učenja, slušanja glazbe i sl.), a obilježja tzv. generacije s društvenih mreža vidljive su kroz slobodu, kreativnost, izbor, integritet, inovacije i otvorenost [1]. Društvene mreže omogućuju mladim generacijama izbore prijatelja, uređivanja fotografija i izrade video uradaka, sudjelovanja u humanitarnim akcijama, promoviranja političkih stavova, itd. [2].

Korisnici društvenih mreža izgrađuju svojevrsnu internetsku socijalizaciju. Mladi rutinski svakodnevno provjeravaju informacije o aktivnostima koje su vezane uz njihove kontakte s društvenih mreža, eksperimentirajući povremeno s vlastitim identitetom sukladno nekim trendovima, čak i kad to ne odgovara stvarnom stanju stvari [4]. Zajednički interes glavno je obilježje svih društvenih mreža. On okuplja grupe ljudi i daje popularnost svim društvenim mrežama [5].

Društvena mreža Facebook, danas je najpopularnija, postavši sociološki fenomen i nova forma društvenog i globalnog komuniciranja. Ta mreža postaje način života, pridonosi sklapanju prijateljstava, upoznavanju novih kultura i razvoju različitih popratnih sadržaja[6]. Statistički podaci iz 2010. godine pokazali su kako je Facebook imao više od 500 milijuna aktivnih korisnika [6]. Društvena mreža Twitter pojavila se 2006. godine, a 2013. zabilježila brojku od 200 milijuna korisnika, postavši danas druga najpopularnija društvena mreža. Twitter u Republici Hrvatskoj [RH] koriste pretežno osobe u dobi od 17 do 26 godina [7].

Komunikacija s društvenih mreža prenosi svoja obilježja i u stvarni svijet, očitujući se kroz sve veću upotrebu novih riječi, ponajviše utemeljenih na posuđenicama iz engleskog jezika [8]. Umjesto učitelja i roditelja sve više ih odgaja utjecaj koji dolazi s različitih društvenih mreža. Zaštita je privatnih sadržaja narušena zbog mogućnosti hakiranja, ali i medijske nepismenosti samih korisnika koji često impulzivno iznose činjenice te prepričavaju vlastite događaje za koje društvene mreže ne predstavljaju sigurno mjesto [8].

\section{Društvene mreže i zdravlje}

U najširem smislu, utjecaj medija obuhvaća sve procese ponašanja i doživljavanja koji se svode na činjenicu da je čovjek primatelj masovne komunikacije [9]. Utjecaj medija stoga može voditi pogubnim posljedicama za odgoj, posebno za mlađu djecu koja su podložnija utjecaju različitih vrsta [10]. Utjecaj medija na korisnika ovisi o izboru samog medija, vremenu korištenja, selekciji sadržaja, uvjetima korištenja i obilježjima članova grupe [11]. Ukoliko primarni čimbenici socijalizacije (ponajviše roditelji) počnu s ograničavanjem i usmjeravanjem gledanja na pozitivne i kvalitetne sadržaje još u ranoj dobi djeteta, negativan će se utjecaj medija smanjiti.

Utjecaj medija po vremenskome kriteriju može se klasificirati na kratkoročni, srednjoročni i dugoročni utjecaj [10]. Dugoročni utjecaj stvara ovisnost, s čime je povezan i izbor medijskih sadržaja. Primjerice, kad djeca gledaju televiziju (TV) više od tri sata dnevno, češće odabiru zabavne sadržaje, a gledaju li TV samo jedan sat dnevno, preferiraju obrazovne sadržaje [12]. Mediji odgojno poželjno djeluju kad kod djece potiču učenje, razvijanje nadarenosti, lijepog ponašanja, te naglašavaju pozitivne vrijednosti [10]. Negativni utjecaji odnose se na ograničenja i ugrožavanje prirode društvenih zajednica, ali i samog ljudskog bića, kao što su pojave ovisnosti, pretilosti, gubljenja socijalnih vještina, „zaglupljivanje“ uslijed previše informacija, mržnja, cyber bulling-a, nasilje, narušavanje privatnosti te rizici izloženosti pornografiji i opasnosti pedofilije [13]. Korištenje interneta kod djece i mladih djeluje na četiri područja. Na tjelesno zdravlje djeluju brojne posljedice prekomjernog korištenja internetskih usluga. Pozitivan je utjecaj na razvoj akademskih i spoznajnih vještina, a negativan utjecaj se pokazuje u mogućnosti pojave depresije i nasilnog ponašanja. Nadalje, dolazi do obrnute socijalizacije, gdje djeca roditelje uče medijskoj pismenosti, što narušava roditeljski autoritet. Konačno, poremećuje se percepcija stvarnosti koja se prvo javlja kao igra virtualnim identitetima, a kasnije nerijetko prelazi u nemogućnost razgraničenja između virtualnog i stvarnog svijeta [13].

\section{Digitalni urođenici i ovisnost o internetu}

Današnja generacija mladih, počevši od osnovnoškolaca, uronjena je u virtualni svijet koji im pružaju mediji i digitalne tehnologije, što sve češće dovodi do negativne pojave socijalno izoliranih pojedinaca, nazvanih digitalnim urođenicima, $Y$ ili "net" generacijom [15]. Oni se rađaju i odrastaju s novom tehnologijom, razlikujući se od osoba koje su rođene prije digitalnog razvoja (tzv. digitalnih useljenika) [15]. Osobine svih digitalnih urođenika brzo je korištenje i primanje informacija, "multitasking", preferiranje grafike umjesto teksta, te preferiranje nasumičnog (hiperteksta) umjesto linearnog pristupa. Svi urođenici teže umreženom djelovanju, trenutnom zadovoljenju želja, učestalim nagradama i igri [15].

Kod ljudi, koji neracionalno koriste internet, javlja se internetska ovisnost, koja se ponajprije očituje u smanjenju socijalne interakcije [15]. Ovisnost o internetu je psihološki poremećaj, osnovan na poremećaju samokontrole u pona- 
šanju ili tehnološkoj ovisnosti. Definira se kao nemogućnost pojedinaca da kontroliraju svoju uporabu internetskih sadržaja, što ima za rezultat tjeskobu i funkcionalne poremećaje u svakodnevnom životu [11]. Ova ovisnost nije razmjerna vremenu provedenom na internetu, nego je povezana s činjenicom da se odbijaju ostale aktivnosti, a vrijeme se troši na virtualni svijet. „Umreženi usamljenici“ u virtualnome svijetu vide zapravo bijeg od usamljenosti, no on ih k tome još više osamljuje. Neracionalno korištenje interneta dovodi do smanjenja snage emocija, koncentracije, pamćenja i kontemplacije, a smanjuje se i osjećaj privrženosti [11]. Naime, izostanak neposredne komunikacije uvjetuje socijalnu izoliranost, smetnje u obiteljskom životu, digitalni narcizam ili neempatičnost [11]. Predugi boravak u virtualnome svijetu dovodi učenike do zapostavljanja svojih obaveza, a takvi mladi ljudi, kao psihosocijalno nezrele jedinke, imaju 2-3 puta veći rizik od depresije od onih koji internet koriste racionalnije [11].

U tijeku 2015. godine je u RH zabilježeno najviše ovisnika o internetu u dobi između 20 i 30 godina i procjenjuje se da taj broj iznosi oko 130000 osoba [14]. U svijetu, procjenjuje se da u ukupnoj populaciji korisnika interneta ima 5-10\% onih koje možemo nazvati ovisnicima o internetu [15]. Prva istraživanja vezana uz ovisnost o internetu počela je provoditi dr. Kimberly Young iz Sjedinjenih Američkih Država 1996. godine, označivši ovaj fenomen kao novi poremećaj kontrole nagona, koji nije vezan uz djelovanje opojnih sredstava [5]. Psihološki znakovi ovisnosti o internetu očituju se na više načina: u nemogućnosti procjene vremena provedenog na internetu; manjku funkcionalnosti u rješavanju svakodnevnih problema (na poslu, u školi ili kod kuće); izolaciji od obitelji i prijatelja; zaštitničkom stavu prema korištenju internetskih usluga; u osjećaju euforije i zadovoljstva tijekom korištenja interneta, kao i u osjećajima vezanim uz neraspoloženje, depresiju, nervozu i povučenost; povećanje tolerancije uz gubitak interesa za ostale aktivnosti; emocionalnu zatvorenost u slučaju nemogućnosti njegova korištenja; pokazivanje neiskrenih osjećaja koji se povezuju s učestalim lažnim iskazivanjem [11]. Tjelesni simptomi, zajednički većini ovisnika o internetu, jesu: bol i ukočenost u rukama i zglobovima; suhe i napete oči; nedostatak sna; glavobolje i bolovi u leđima i vratu; pogoršanje fizičkog izgleda; pretjerano mršavljenje ili debljanje; loša koordinacija pokreta i promjene prehrambenih navika [11].

Posebnu opasnost kod osnovnoškolaca, ali i kod djece starijeg uzrasta, može predstavljati nemogućnost prepoznavanja znakova manipulacije, što dovodi do nepravovremenog djelovanja. Ovisnost o internetu kod djeteta posebno utječe na njegovu nedovoljnu socijaliziranost i razvijanje socijalnih vještina, pa se takvo dijete suočava s nizom poteškoća kada u realnome svijetu žele sklopiti prijateljstvo [11]. Budući da internet dopušta osobama da se predstave onako kako žele da ih drugi vide, to utječe i na razvoj djetetove slike o sebi, koja se u ovom slučaj formira na temelju onoga što misli netko o tome kako ga drugi vide [11].

Glavni cilj ovog istraživanja utvrditi je način korištenja online društvenih mreža kod učenika viših razreda osnovne škole te identificirati različita ponašanja učenika na online društvenim mrežama.
Istraživanjem se željelo utvrditi i odgovore na pojedinačna pitanja: posjeduju li učenici na online društvenim mrežama svoj profil, kolika je učestalost korištenja i količina vremena provedenog na društvenim mrežama, zašto učenici koriste društvene mreže, koliki broj prijatelja imaju na svojim profilima, koriste li im se roditelji računalima i misle li da im roditelji misle da provode previše vremena na računalom, jesu li im prijateljstva koja imaju putem društvenih mreža površna, rastužuje li ih kad vide da druge osobe imaju velik broj prijatelja na društvenim mrežama, te mogu li zamisliti svoj život bez društvenih mreža.

\section{Metode / Methods}

\section{Ispitanici}

Istraživanje je provedeno na namjerno odabranom uzorku od 225 učenika viših razreda (od 5.do 8. razreda) Osnovne škole "Lapad" u Dubrovniku. Struktura anketiranih učenika prema spolu ukazuje da je nešto veći broj dječaka $(127, \mathrm{tj}$. 56,44\%), nego djevojčica (98, tj. 43,56\%). Rezultati Hi-kvadrat testa uz 5\% signifikantnosti ( $c 2=3,7378$; df $=1 ; p=$ 0,0532) ukazuju da razlika između broja dječaka i djevojčica nije statistički značajna. Raspodjela po dobi anketiranih pokazuje da je 19,56\% (44) učenika u dobi od 10 do 11 godina, $42,67 \%$ (96) u dobi od 12 do 13 godina te $37,78 \%$ (37,78\%) u dobi od 14 do 15 godina. Prema aritmetičkoj sredini, prosjek je 12,86 godina. Hi-kvadrat test (c2 = 20,0267; df = 2; $\mathrm{p}=0,00$ ) pokazuje da postoji statistički značajna razlika u godinama starosti. Struktura anketiranih po razredima pokazuje da je najmanji broj ispitanih učenika iz V. razreda $(22,22 \%$, tj. 50), po $23,11 \%$ (po 52) ih je bilo u VI. i VII. razredu, dok je nešto veći broj učenika VIII. razreda (31,56\%). Rezultati Hi-kvadrat testa pokazuju da ne postoji statistički značajna razlika u broju učenika po razredima (c2 = 5,2044; $\mathrm{df}=3 ; \mathrm{p}=0$,1574). Anketirani učenici većinom uglavnom imaju prebivalište u gradu (221 ili 98,22\%), dok su samo 4 $(1,78 \%)$ bila iz prigradskih naselja, a sa seoskog područja nije bilo niti jednog učenika.

\section{Postupak i varijable}

Istraživanje je provedeno u periodu od 30. 4. do 18. 5. 2015. godine. Podatci su prikupljeni uz suglasnost (potpisani informirani pristanak) roditelja djece koja su sudjelovala u istraživanju kao i ravnatelja Osnove škole „Lapad“ u Dubrovniku. Ukupno je ispitano 225 učenika i to upitnikom koji su nastavnici podijelili učenicima tijekom redovite školske nastave. Ispunjavanje upitnika trajalo je najviše 5 minuta.

$\mathrm{U}$ radu je korišten anketni upitnik sastavljen od 22 pitanja i izrađen za potrebe ovog istraživanja. Učenici su na ponuđene odgovore DA ili NE mogli zaokružiti jednu od mogućnosti. Za pitanja izražena na Likertovim ljestvicama, u rasponu od 1-uopće se ne slažem, do 5-u potpunosti se slažem ili pak od 1-nikad, do 5-uvijek, ispitanici su trebali također zaokružiti po jedan ponuđeni odgovor, koji najbolje opisuje njihovo ponašanje. Prikupljeni podaci iz upitnika uneseni su u Microsoft Excel tablice prema unaprijed pripremljenom kodnom planu. 


\section{Statističke analize}

Statistička analiza podataka izvršena je analizom frekvencija i postotaka, a podaci su prikazani u tablicama. Za varijable ordinalnog tipa izračunati su medijani, a razlike u raspodjelama broja ispitanika po pojedinim kategorijama izračunate su primjenom Hi-kvadrat testa, putem online kalkulatora na mrežnoj stranici: http://www.testovi.info/hikvadrat-test-kalkulator.html

\section{Rezultati / Results}

Podaci ankete pokazuju da velika većina ispitanih učenika posjeduje računalo, tj. 186 (82,67\%), dok samo 39 (17,33\%) ne posjeduje računalo. Prema trajanju korištenja interneta, podaci pokazuju da 61 (32,80\%) anketirani koristi računalo manje od jedne godine, njih 83 (44,62\%) između jedne i 5 godina, dok $41(22,04 \%)$ ispitanik koristi računalo više od 5 godina. Medijan (1-5 godina) pokazuje da je prosječno korištenje računala između jedne i pet godina.

Bez obzira na činjenicu posjeduju li ispitanici računalo ili ne, svi znaju koristiti i koriste internet. Na pitanje o učestalosti korištenja računala $61(27,11 \%)$ ispitanik upotrebljava računalo svakodnevno, 66 (29,33\%) više puta tjedno, 29 $(12,89 \%)$ više puta mjesečno, a njih 60 (26,67\%) rijetko. Prema vrijednosti medijana, prosječno se računalo koristi više puta tjedno [tablica 1].

Prema broju i vrsti uređaja za pristup internetu, najveći broj ispitanika (112 ili 50,22\%) koristi samo mobilni telefon, zatim slijede oni koji koriste samo desktop računalo (46 ili $20,63 \%)$. Na trećem mjestu su oni koji koriste sva tri uređaja (33 ili 14,80\%). Manji broj ispitanika koristi mobilni telefon

TABLICA [1] Raspodjela anketiranih prema učestalosti korištenja računala

\begin{tabular}{lcc}
\hline Učestalost korištenja & Broj & $\%$ \\
\hline Svakodnevno & 61 & 27,11 \\
\hline Više puta tjedno & $\mathbf{6 6}$ & $\mathbf{2 9 , 3 3}$ \\
\hline Više puta mjesečno & 29 & 12,89 \\
\hline Rijetko & 60 & 26,67 \\
\hline Nikada & 5 & 2,22 \\
\hline Bez odgovora & 4 & 1,78 \\
\hline Ukupno & 225 & 100,00 \\
\hline
\end{tabular}

Bold - medijan i desktop računalo (11 ili 4,93\%), te mobilni telefon i tablet računalo (8 ili 3,59\%). Hi-kvadrat test $\left(c^{2}=61,2727\right.$; df $=2 ; p$ $=0,000$ ) pokazuje da postoji statistički značajna razlika u korištenju različitih uređaja za pristup internetu [tablica 2].

Najveći broj ispitanika je na pitanje o učestalosti spajanja na internet odgovorio da se spaja svakodnevno (njih 145 ili $65,32 \%)$, dok se više puta tjedno spaja njih44 ili 19,82\%. Više puta mjesečno spaja se 8 ispitanika (3,60\%), a rijetko se spaja $21(9,46 \%)$ ispitanik. Samo 4 ispitanika (1,80\%) uopće se ne spaja na internet. Medijan pokazuje da se ispitanici u prosjeku spajaju na internet svakodnevno.

Prema vrijednostima medijana za svaki razlog spajanja na internet, može se zaključiti da su u prosjeku česti razlozi muzika i filmovi kao i komunikacija na društvenim mrežama. Ponekad se ispitanici spajaju zbog igrica kao i zbog ostalih razloga. $U$ prosjeku se ispitanici rijetko spajaju na internet zbog preuzimanje podataka - učenja [tablica 3].

Analiza prema posjedovanju profila na društvenoj mreži pokazuje da većina ispitanika, njih 200 (88,89\%) ima svoj profil na nekoj društvenoj mreži.

Podaci o raspodjelama ispitanika prema vrsti društvene mreže pokazuju da je najzastupljeniji Facebook sa 174 od 225 anketiranih ili 77,33\%. Nakon Facebooka slijedi Instagram sa 136 ispitanika ili 60,44\%. Twitter je zastupljen s 40 ispitanika (17,78\%), a drugemreže sa 79 ispitanika ili 35,11\%. Prema rezultatima Hi-kvadrat testa $\left(c^{2}=98,8601 ; \mathrm{df}=3 ; \mathrm{p}=\right.$ 0,000 ) postoji statistički značajna razlika u vrsti društvenih mreža [tablica 4].

TABLica [2] Raspodjela prema broju i vrsti uređaja za pristup internetu

\begin{tabular}{lll}
\hline Uređaj & Broj & $\%$ \\
\hline samo desktop računalo & 46 & 20,63 \\
\hline samo mobilni telefon & 112 & 50,22 \\
\hline samo tablet računalo & 13 & 5,83 \\
\hline mobilni telefon i desktop računalo & 11 & 4,93 \\
\hline mobilni telefon i tablet računalo & 8 & 3,59 \\
\hline desktop i tablet računalo & 0 & 0,00 \\
\hline sva tri uređaja & 33 & 14,80 \\
\hline Ukupno & 223 & 100,00 \\
\hline
\end{tabular}

TABLICA [3] Učestalost pristupa na internet s obzirom na razlog pristupanja

\begin{tabular}{lccccccc}
\hline Razlog & nikad & rijetko & ponekad & često & uvijek & ukupno & medijan \\
\hline Igrice & 29 & 61 & 46 & 34 & 52 & 222 & ponekad \\
\hline Muzika i filmovi & 13 & 25 & 46 & 68 & 68 & 220 & često \\
\hline Komunikacija na društvenim mrežama & 27 & 28 & 30 & 43 & 93 & 221 & često \\
\hline Preuzimanje podataka - učenje & 59 & 56 & 61 & 27 & 17 & 220 & rijetko \\
\hline Ostalo & 44 & 25 & 26 & 34 & 27 & 156 & ponekad \\
\hline
\end{tabular}


TABLICA [4] Raspodjela ispitanika prema vrsti društvene mreže

\begin{tabular}{lcc}
\hline Mreža & Broj & $\%$ \\
\hline Facebook & 174 & 77,33 \\
\hline Twitter & 40 & 17,78 \\
\hline Instagram & 136 & 60,44 \\
\hline drugo & 79 & 35,11 \\
\hline
\end{tabular}

Na pitanje o učestalosti posjeta društvenim mrežama najveći broj ispitanika (147 ili 72,41\%) odgovorio je da svakodnevno posjećuju društvene mreže, 2-3 put tjedno društvene mreže posjećuje 31 ispitanik (15,27\%), dok ih 25 (12,32\%) rijetko posjećuje društvene mreže. Medijan ukazuje da ispitanici u prosjeku posjećuju društvene mreže svakodnevno [tablica 5].

U odnosu na raspodjelu prema broju prijatelja na profilu društvene mreže, medijan pokazuje da je u prosjeku preko 200 prijatelja na profilu. Do 50 prijatelja ima $37(18,41 \%)$ anketiranih, do 100 njih 22 (10,95\%), do 200 ima 32 ispitanika $(15,92 \%)$, a preko 200 prijatelja ima 110 (54,73\%) ispitanika.

$\mathrm{U}$ odnosu na vrijednost medijana za svaki od razloga korištenja društvene mreže, kao najvažniji razlog pokazalo se druženje s postojećim prijateljima, u čemu se ispitanici u prosjeku potpuno slažu. Za upoznavanje novih ljudi kao razlog za korištenje društvene mreže, ispitanici se u prosjeku uglavnom ne slažu. Ispitanici se u prosjeku uglavnom ne slažu ili nisu sigurni da su razlog za društvene mreže upoznavanje novih ljudi ili ostali razlozi [tablica 6].

Većina roditelja, tj. 141 (68,45\%) aktivno se koristi računalom, dok se 65 roditelja $(31,55 \%)$ ne koristi računalom prema mišljenju njihove djece.
TABLICA [5] Učestalost posjeta društvenim mrežama

\begin{tabular}{lcc}
\hline Učestalost & Broj & \% \\
\hline svakodnevno & $\mathbf{1 4 7}$ & $\mathbf{7 2 , 4 1}$ \\
\hline 2-3 puta tjedno & 31 & 15,27 \\
\hline rijetko & 25 & 12,32 \\
\hline Ukupno & 203 & 100,00 \\
\hline
\end{tabular}

Bold - medijan

Što se tiče mišljenja roditelja o tome provode li djeca previše vremena za računalom, većina roditelja (127 ili $61,35 \%)$ misli da anketirani učenici provode previše vremena za računalom, dok (80 ili 38,65\%) smatra da ne provode previše vremena za računalom.

S mišljenjem: „prijateljstva koja imam putem društvenih mreža su površna", ispitanici, s obzirom na vrijednost medijana, u prosjeku nisu sigurni slažu li se sa sadržajem tvrdnje ili ne. U pogledu mišljenja: „Rastužuje me kad vidim da druge osobe imaju velik broj prijatelja na društvenim mrežama", prema vrijednosti medijana, ispitanici se u prosjeku uopće ne slažu s ovom tvrdnjom. Konačno, s tvrdnjom: „Posjedujem više profila na društvenim mrežama jer se tako osjećam poželjniji/a", s obzirom na vrijednost medijana, ispitanici se uopće ne slažu (tablica 7).

U odnosu na mišljenje: „mogu li ispitanici zamisliti život bez društvenih mreža", od 204 ispitanika koji su odgovorili na ovo pitanje, njih $126(61,76 \%)$ smatra da može, dok preostalih $78(38,24 \%)$ smatra da ne može zamisliti život bez društvenih mreža.

TABLICA [6] Stupanj slaganja s razlozima za pristup društvenim mrežama

\begin{tabular}{lllllll}
\hline \multirow{2}{*}{ Razlozi } & \multicolumn{7}{c}{ Stupanj slaganja } & Medijan \\
\cline { 2 - 6 } & $\mathbf{1}$ & $\mathbf{2}$ & $\mathbf{3}$ & $\mathbf{4}$ & $\mathbf{5}$ & $\mathbf{5}$ \\
\hline Druženje s postojećim prijateljima & 13 & 11 & 18 & 62 & 96 \\
\hline Upoznavanje novih ljudi & 65 & 37 & 45 & 30 & 25 & 2 \\
\hline Predstavljanje događaja iz svog života & 58 & 43 & 47 & 31 & 23 & $2-3$ \\
\hline Ostalo & 52 & 7 & 16 & 18 & $2-3$ \\
\hline
\end{tabular}

Legenda: 1=uopće se ne slažem, 2=uglavnom se ne slažem, 3=nisam siguran/a, 4=uglavnom se slažem, 5=u potpunosti se slažem

TABLICA [7] Raspodjela ispitanika prema stupnju slaganja o tri tvrdnje vezane uz društvene mreže

\begin{tabular}{|c|c|c|c|c|c|c|}
\hline \multirow{2}{*}{ Razlozi } & \multicolumn{5}{|c|}{ Stupanj slaganja } & \multirow{2}{*}{ Medijan } \\
\hline & 1 & 2 & 3 & 4 & 5 & \\
\hline Prijateljstva preko društvenih mreža su površna. & 45 & 36 & 71 & 37 & 13 & 3 \\
\hline $\begin{array}{l}\text { Rastužuje me kad vidim da druge osobe imaju velik } \\
\text { broj prijatelja na društvenim mrežama. }\end{array}$ & 153 & 24 & 20 & 2 & 6 & 1 \\
\hline $\begin{array}{l}\text { Posjedujem više profila na društvenim mrežama jer } \\
\text { se tako osjećam poželjniji/a. }\end{array}$ & 151 & 18 & 15 & 12 & 7 & 1 \\
\hline
\end{tabular}

Legenda: 1=uopće se ne slažem, 2=uglavnom se ne slažem, 3=nisam siguran/a, 4=uglavnom se slažem, 5=u potpunosti se slažem 


\section{Rasprava / Discussion}

Premda ispitani uzorak učenika nije potpuno reprezentativan za populaciju dubrovačkih osnovnoškolaca viših razreda osnovne škole, moguće je identificirati tendencije u načinu korištenja društvenim mrežama i različita ponašanja na društvenim mrežama kod učenika viših razreda osnovne škole, te otvoriti neka nova problemska područja u istraživanju ovoga društvenog fenomena [13]. Opći nalaz istraživanja ukazuje da su društvene mreže postale sastavnim dijelom života osnovnoškolaca, dok rezultati tek djelomično mogu davati optimistična predviđanja o njihovim implikacijama na zdravlje djece.

Podaci pokazuju da veliki broj djece (preko 80\%) posjeduje računalo, a svi ispitanici imaju iskustvo korištenja računala od 1 do 5 godina. Učenici koriste računalo svakodnevno, najčešće pristupajući internetu putem mobilnog telefona, ali i na druge načine. Najčešći su razlozi spajanja na internet slušanje glazbe i gledanje filmova, uz komunikaciju na društvenim mrežama, dok se internet najmanje koristi u obrazovne svrhe. Oko $90 \%$ ispitanih učenika ima svoj profil na nekoj društvenoj mreži (najčešće na Facebooku) ili na više njih. Društvene mreže učenici posjećuju svakodnevno, i u prosjeku imaju više od 200 prijatelja. Glavni razlog korištenja društvene mreže druženje je s postojećim prijateljima, a rijetko je motiv upoznavanje novih ljudi. Roditelji ispitanika smatraju da njihova djeca provode previše vremena za računalom. Optimističan je podataka da oko $62 \%$ djece može zamisliti svoj život bez društvenih mreža.

Na temelju rezultata istraživanja može se zaključiti da su društvene mreže postale sastavnim dijelom života osnovnoškolaca. Njihova svakodnevna višesatna uporaba potencijalno ih vodi do ovisnosti, koju je potrebno liječiti, ili, što je još bolje, prevenirati. Posebna opasnost od ovisnosti sastoji se u zanemarivanju uobičajenih životnih navika i zaduženja da bi se provelo što više vremena na internetu. Također, postoji opasnost da virtualni svijet služi kao zamjena za realne socijalne kontakte i druženja. Opasnost prijeti i od nemogućnosti djeteta da kontrolira vrijeme provedeno na internetu i pronalaska lažnih opravdanja za vlastito ponašanje. Neki mogu osjećati i krivnju što provode toliko vremena za računalom, ali ne mogu na to utjecati i maknuti se svojom voljom [15]. Drugi se pak, ako se internetska veza prekine ili je u kvaru, osjećaju izgubljeno, uznemireno i lošeg su raspoloženja [15]. Činjenica da učenici na svojim Facebook-profilima imaju veliki broj prijatelja može ukazivati na pogrešno i/ili površno shvaćanje pojma "prijatelj” u online društvenim mrežama [13]. Premda je veliki postotak roditelja upoznat s činjenicom da im se djeca služe društvenim mrežama, postavlja se pitanje jesu li roditelji upoznati sa svim što njihova djeca rade na društvenim mrežama i kojim su opasnostima djeca izložena. Pretpostavimo li da su učenici iskreno odgovarali na postavljena pitanja (s obzirom da im je pri ispitivanju garantirana anonimnost), može se zaključiti da roditelji nisu upoznati s uvjetima korištenja online društvenih mreža, o čemu govori i podatak da učenici posjeduju Facebook-profil prije dozvoljene (preporučene) dobne granice za koju bi to bilo poželjno. Također, moguće je problematizirati i činjenicu o sve ranijoj upotrebi računala i ulaženju u svijet društvenih mreža sve mlađe djece. I dok se u znanstvenoj i stručnoj javnosti sve glasnije proklamira ideja o važnosti informatičke pismenosti, malo je onih koji govore o pravilnoj i „zdravoj" upotrebi ove sveprisutne tehnologije [11].

Rezultati daju smjernice za poduzimanje odgojno-obrazovnih akcija, u svrhu minimaliziranja negativnih, a poticanja pozitivnih učinaka društvenih mreža. Zbog toga se javlja potreba za usmjeravanjem osnovnoškolaca na konstruktivno korištenje društvenih mreža, kako bismo na što bolji i učinkovitiji način iskoristili njihove potencijale. $U$ tom usmjeravanju bitan faktor predstavljaju roditelji koji samo demokratskim ili autoritativnim odgojem pridonose formiranju mladih osoba koje će imati produktivnu ulogu unutar zajednice. Nove generacije moraju znati iskoristiti sve mogućnosti koje im pružaju mediji kroz odgojne, informativne i didaktičke programe, dok zabava i spektakularnost trebaju ostati podređeni [6]. Da bi učenik mogao opstati u modernom informacijskom društvu, mora se znati kompetentno koristiti medijima. Pritom se treba pridržavati svih mjera opreza na koje upućuju medijski pedagozi, kojima je glavna uloga pročitati sublimirane poruke, odnosno otkriti skrivene poruka kojima mediji nastoje zavesti učenike [16]. Njihova se temeljna zadaća sastoji u tome da nauče svakog osnovnoškolca, ali i starije dobne skupine, kako uočiti i odvojiti pozitivne od negativnih medijskih poruka i utjecaja, kako bi učenici sami mogli "filtrirati“ dobivene informacije, uklonivši time mogućnost da sami postanu objektom medijske manipulacije [2]. Naime, pokazalo se da mediji zapravo nisu ni potpuno negativni, a ni potpuno pozitivni, već njihov učinak uveliko ovisi o tome kako ih pojedinac koristi. Prekomjerna uporaba medija ili posebice društvenih mreža, učenika dovodi u stanje ovisnosti, narušavajući mu zdravlje [15].

Među prednostima istraživanja svakako treba istaknuti prikupljanje relevantnih podataka na razmjerno velikom uzorku ispitanika o problematici odnosa korištenja društvenih mreža i potencijalnih zdravstvenih korelata, kod starijih osnovnoškolaca na jednom specifičnom lokalitetu. Nedostaci istraživanja mogu se većinom sažeti na primjenu nestandardiziranog instrumentarija za prikupljanje podataka, na uzorak koji nije u potpunosti reprezentativan, koji može biti specifičan za određeno područje s relativno iznadprosječnim standardom za urbanu populaciju učenika u RH.

Stoga se smjernice za buduća istraživanja mogu svesti na organiziranje istraživanja s ispitivanjem većeg i stratificiranog uzorka učenika, reprezentativnog za populaciju hrvatskih starijih osnovnoškolaca, po mogućnosti uz postavljanje dodatnih pitanja primjenom standardiziranog instrumentarija za prikupljanje podataka.

\section{Zaključak/Conclusion}

Podaci pokazuju da veliki broj djece $(82,67 \%)$ posjeduje računalo, dok sva djeca koriste računalo, i to s iskustvom od jedne i pet godina. Djeca prosječno koriste računalo više puta tjedno (u prosjeku svakodnevno) i najčešće pristupaju internetu putem mobilnog telefona (u gotovo dvije trećine slučajeva). Najčešći su razlozi spajanja na internet glazba i filmovi kao i komunikacija na društvenim mrežama, dok je 
rijedak razlog spajanja na internet radi obrazovnih podataka. Većina ispitanika $(88,89 \%)$ ima svoj profil na nekoj društvenoj mreži (najčešće na Facebooku), a ispitanici su često uključeni u više društvenih mreža koje svakodnevno posjećuju, s više od 200 prijatelja na profilu određene društvene mreže. Glavni razlog učlanjenja u određenu društvenu mrežu ispitanicima je druženje s postojećim prijateljima. Roditelji ispitanika aktivno se koriste računalom u 68,45\% slučajeva i smatraju da njihova djeca provode previše vremena za računalom. Oko 62\% djece vjeruje da može zamisliti svoj život bez društvenih mreža. Na temelju dobivenih rezultata, razvidno je da su društvene mreže postale sastavni dio života osnovnoškolaca, dok se tek u manjoj mjeri mogu davati optimistična predviđanja o njihovim implikacijama na zdravlje djece.

\section{Authors declare no conflict of interest}

\section{Literatura / References}

[1] Pasqualetti F, Nanni C. Novi mediji i digitalna kultura. Izazov odgoju. Zagreb: Kateheza; 2005.

[2] Ilišin V, Bobinac Marinović A, Radin F. Djeca i mediji: Uloga medija u svakodnevnom životu djece. DZOMM/IDIZ; 2001.

[3] Kunczik M, Zipfel A. Uvod u znanost o medijima i komunikologiju. Zagreb: Zaklada Friedrich Ebert; 2006.

[4] Christakis NA. Povezani: iznenađujuća moć društvenih mreža i kako one utječu na naše živote. Zagreb: Algoritam; 2010.
[5] Puharić $Z$, Stašević I, Ropac D, Petričević N, Jurišić I. Istraživanje čimbenika nastanka ovisnosti o internetu. Acta Med Croatica, 2014; 68: 361-373.

[6] Kušić S. Online društvene mreže i društveno umrežavanje kod učenika osnovne škole: Navike Facebook generacije.Život i škola, 2010; 56(24): 103-125.

[7] Grbavac J, Grbavac V. Pojava društvenih mreža kao globalnog komunikacijskog fenomena. Media, Culture and Public Relations, 2014 5(2): 206-219.

[8] Miliša Z, Tolić M, Vertovšek N. Mediji i mladi. Zagreb: Sveučilišna knjižara; 2009.

[9] Kunczik M, Zipfel A. Uvod u znanost o medijima i komunikologiju. Zagreb: Zaklada Friedrich Ebert; 2006.

[10] Rožić I. Utjecaj medija na vrijednosni sustav mladih u Splitu i Padovi. Diplomski rad. Split: Ekonomski fakultet.

[11] Carević N, Mihalić M, Sklepić M. Ovisnost o internetu među srednjoškolcima. Socijalna politika i socijalni rad, 2014; 2(1): 64-81.

[12] Ilišin V. Mediji u slobodnom vremenu djece i komunikacija o medijskim sadržajima. Medijska istraživanja, 2003; 9(2): 9-34.

[13] Nikodem K, Kudek Mirošević J, Bunjevac Nikodem S. Internet i svakodnevne obaveze djece, Analiza povezanosti korištenja interneta i svakodnevnih obaveza zagrebačkih osnovnoškolaca. Socijalna ekologija, 2015; 23(3): 211-236.

[14] Internet. Zagreb: Hrvatski zavod za javno zdravstvo; 2015. http:// www.hzjz.hr/wp-content/uploads/2015/11/hzjz-INTERNET-2-refined. pdf (datum preuzimanja 29. rujna 2015.).

[15] Miliša Z, Tolić M. Kriza odgoja i ekspanzija suvremenih ovisnosti. Medianali, 2010; 4(8): 135-154.

[16] Tolić M. Medijska kompetencija kao prevencija pri sprečavanju medijske manipulacije u osnovnim školama. Medianali, 2009; 3(6): 195212. 